\title{
PW02-040 - Low-penetrance NLRP3 variants
}

\author{
T Endres ${ }^{1}$, F Hofer ${ }^{1}$, R Goldbach-Mansky² ${ }^{2}$ HM Hoffman ${ }^{3}$, N Blank ${ }^{4}$, K Krause $^{5}$, C Rietschel ${ }^{6}$, G Horneff ${ }^{7}$, P Lohse ${ }^{8}$, \\ J Kuemmerle-Deschner ${ }^{1 *}$
}

From 7th Congress of International Society of Systemic Auto-Inflammatory Diseases (ISSAID) Lausanne, Switerland. 22-26 May 2013

\section{Introduction}

Cryopyrin-associated periodic syndrome (CAPS) presents as rare, autosomal dominant disease spectrum, due to mutations in the NLRP3 gene which result in an excessive interleukin-1 (IL-1) release.

In patients with low-penetrance NLRP3 variants, the clinical presentation varies widely. So far, a correlation with a specific phenotype could not be demonstrated.

\section{Objectives}

The aim of this study was to analyze the association of the V198M, R488K, and Q703K substitutions with a specific phenotype, laboratory markers, and the response to IL-1 inhibitors anakinra and canakinumab.

\section{Methods}

This multi-center observational study included 44 patients ( 25 children and 19 adults). All patients were symptomatic with some symptoms suggesting possible CAPS at the time of baseline examination. Genetic analysis detected one of the following NLRP3 variants: Q703K $(\mathrm{n}=18)$, R488K $(\mathrm{n}=6)$, and V198M $(\mathrm{n}=20)$.

Clinical phenotypes were described and laboratory markers were analyzed. In order to review the response to IL-1 inhibitors, data from follow-up visits were also evaluated.

\section{Results}

At baseline examination, patients reported signs of systemic inflammation such as fever (75\%), headache (73\%), musculoskeletal symptoms (84\%), and fatigue (77\%). Other CAPS-specific features were rash (82\%), conjunctivitis (43\%), and sensorineural hearing loss (25\%).
More than half of the patients (57\%) reported abdominal pain and other gastrointestinal symptoms. A history of gastro-esophageal reflux was described by $23 \%$ of the patients, and $39 \%$ of the patients had oral ulcers.

Inflammation markers were only slightly increased: ESR was elevated in $26 \%(n=34)$ and C-reactive protein (CRP) in $38 \%(n=40)$.

Serum amyloid A (SAA) was raised in $36 \%(8 / 22)$ of the patients. Eight out of nine patients $(89 \%)$ had elevated TNF- $\alpha$-levels at baseline examination.

At baseline evaluation, 25 patients were treated with IL-1 inhibitors (anakinra or canakinumab). Data from follow-up visits during the first year of treatment were available from 21 patients: clinical disease activity was reduced in all cases; five patients (24\%) achieved full remission, 13 (62\%) still had mild symptoms, and three patients (14\%) showed only a partial response.

\section{Conclusion}

Heterozygous carriers of NLRP3 variants V198M, R488K, and Q703K display distinct clinical characteristics compared to CAPS patients with definite disease causing mutations, including a high incidence of gastrointestinal symptoms, only slightly elevated inflammatory parameters, and a potentially inferior response to IL-1 inhibition.

\section{Competing interests \\ None declared.}

\begin{abstract}
Authors' details
${ }^{1}$ Department of Pediatrics, Division of Pediatric Rheumatology, University Hospital Tuebingen, Tuebingen, Germany. ${ }^{2}$ Translational Autoinflammatory Disease Section, NIAMS/NIH, Bethesda, MD, USA. ${ }^{3}$ Division of Rheumatology and Allergy/Immunology, University of California at San Diego, San Diego, CA, USA. ${ }^{4}$ Hämatologie, Onkologie u. Rheumatologie, Universitätsklinikum Heidelberg, Heidelberg, Germany. ${ }^{5}$ Allergie-Centrum Charité", Klinik für Dermatologie, Charité Campus Mitte, Berlin, Germany. ${ }^{6}$ Kinder- und
\end{abstract}


Published: 8 November 2013

doi:10.1186/1546-0096-11-S1-A181

Cite this article as: Endres et al:: PW02-040 - Low-penetrance NLRP3 variants. Pediatric Rheumatology 2013 11(Suppl 1):A181.

Submit your next manuscript to BioMed Central and take full advantage of:

- Convenient online submission

- Thorough peer review

- No space constraints or color figure charges

- Immediate publication on acceptance

- Inclusion in PubMed, CAS, Scopus and Google Scholar

- Research which is freely available for redistribution

Submit your manuscript at www.biomedcentral.com/submit 